\title{
Effect of Crack Closure on Ultrasonic Testing of FRP Laminates
}

\author{
○学 石川 拓人（神戸市立高専・専攻科）正 和田 明浩（神戸市立高専）
}

Takuto ISHIKAWA, The Advanced Course of Mechanical Systems Engineering, Kobe City College of Technology Akihiro WADA, Department of Mechanical Engineering, Kobe City College of Technology

Effect of crack closure on ultrasonic nondestructive testing of FRP laminates is investigated. Ultrasonic wave velocity is directly related to material stiffness, so that it is a quantitative parameter that gives information about the mechanical state of the material. However, under compressive load, stiffness recovery due to closed cracks might reduce the reliability of the inspected results. In this work, the change in the Lamb wave velocity of composite laminates is evaluated as a function of the bending load. It is confirmed that the wave velocity is enhanced by the applied load corresponding to the stiffness recovery due to closed cracks in the concave part of the laminate.

Key words : Ultrasonic testing, FRP laminates, Bending, Crack closure, Matrix crack

\section{1. はじめに}

FRP (Fiber Reinforced Plastics : 繊維強化プラスチック) 積層板は航空・宇宙分野をはじめ样々な産業分野で構造用材 料として広く普及しているが、使用を続けるに従い、いずれ は多数のマトリックスき裂の発生に伴う材料特性の劣化が 起きる。FRP 積層板は一般に不透明であることが多く、き裂 発生やその位置を視覚に捉えることが困難なため、これまで 超音波による非破壊損伤評価が検討されてきた。しかし、 FRP 積層板は薄板構造のため曲げ荷重を受ける場合も多く、 曲げ荷重下で生じるき裂の閉口が検查結果に悪影響を与え ることが獎念される。そこで本研究では、曲げ荷重を加えた FRP 積層板に超音波を入射し、その伝播特性に与える曲げ荷 重の影響を評価した。

\section{2. 超音波伝播特性に与えるき裂閉口の影粟}

\section{1 超音波による非破埢検査}

超音波による非破壊損稘評価として、超音波探賃がある。 超音波探傷とは欠陥で反射してくる超音波を検出して、欠陥 の有無やその位置を知る非破壊試験である。しかし、複合材 料の場合、欠陷は無数にあるため、個々の欠陷を検出するの は不可能である。そこで本研究では、超音波を欠陷部で反射 させるのではなく、陷を透過してきた超音波を検出するこ とにより、材料の平均的な剛性低下を評価する。

\section{2 曲げ荷重によるき裂の閉口}

き裂を含む FRP 積層板に曲げ荷重を加えると、き裂の一 部が閉口し、あたかも損傷していないように振舞うことがあ る。その概要を図 1 に示す。曲げ荷重により片面に任縮が、 反対面に引張が生じ、圧縮側にあるき裂が閉口する。

図 2 に曲げ荷重を負荷する前後で損傷した試験片の断面を 光学顕微鏡で観察した結果を示す。（a ）は無負荷時の試験片 の断面、（b）は負荷時の試験片の圧縮側断面である。無負荷 時に観察されたき裂が荷重の影響で閉口していることが分
かる。このき裂閉口は積層板の剛性を一時的に上昇させるた め、音速の増加をもたらすことが予想される。

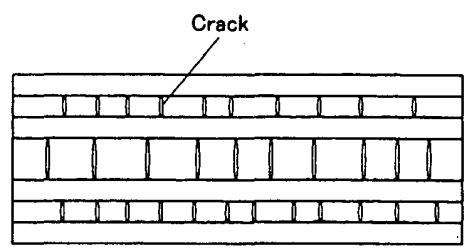

(a ) Before loading



(b) Under bending load

Fig.1 Crack closure due to bending load.

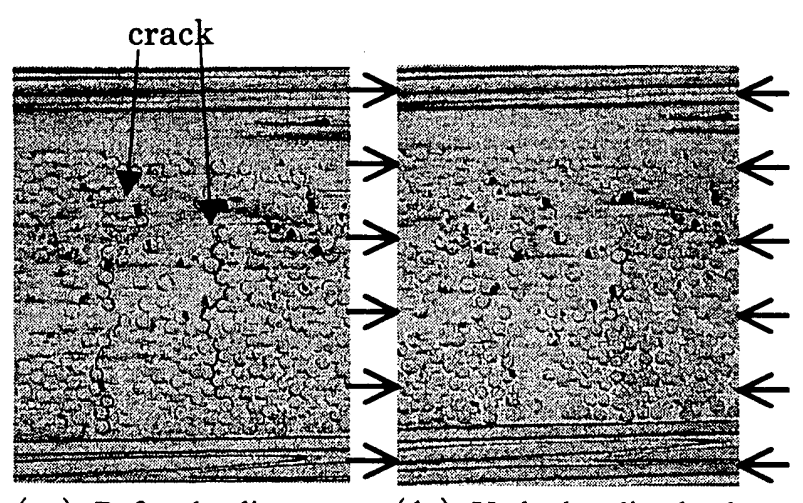

( a ) Before loading

(b) Under bending load

Fig.2 Photographs of specimen cross-section. 


\section{3. 超音波伝播特性の測定}

\section{1 試料}

今回使用する試験片は、母材としてエポキシ樹脂、強化 繊維としてガラス繊維を使用した FRP 穦層板であり、積層 構成は $\left[(0 / 90)_{2 S}\right]$ と $\left[(0 / 90)_{3 \mathrm{~S}}\right]$ を使用した。試料はオートクレ 一ブにより成形した後、 $28 \times 300$ の短冊状に切断して試験 に用いた。その後、損傷状態による違いを調べるため、 $\left[(0 / 90)_{2 \mathrm{~S}}\right]$ には $\left.1400 \mathrm{kgf、[}(0 / 90)_{3 \mathrm{~S}}\right]$ には $1500 \mathrm{kgf}$ の引張荷重 を負荷して試験片に損傷を与えた。

\section{2 音速測定手暊}

図 3 に実験装置を示す。 4 点曲げの要領で試験片に荷重 を負荷し、純曲げの区間の音速を測定した。発信、受信に は中心周波数 $1 \mathrm{MHz}$ の圧電トランスデューサを使用し、ホル ダにより FRP 積層板に直角に接するように $100 \mathrm{~mm}$ 間隔で 設置した。また、センサ前面にアクリルウェッジを取り付 けて試験片との接触面がライン状になるようにした。この 際、超音波の伝達効率を上げるために接触面にはカップラ ントを塗布した。

発信側に $400 \mathrm{~V} 、 500 \mathrm{k} \mathrm{Hz}$ のパルスを入射し、試験片を伝 播した超音波を受信側トランスデューサで検出して、信号 の検出時間と伝播距離より音速を求めた。測定点は図 4 に 示すように超音波形中より 2 箇所とり、測定はFRP 積層板 に加える曲げ荷重を段階的に変化させながら繰り返し行っ た。また、損傷前と損傷後の試験片に対して同様の測定を おこない、損傷の有無による超音波伝播速度の変化を評価 した。

\section{3 音速測定結果}

図 5 は曲げ荷重を段階的に負荷したときと段階的に除荷し たときの音速の変化を示した図である。図中には異なる計測 点を用いた結果の比較および損傷時と非損傷時の試験片の 比較を示している。損傷した試験片の場合、負荷に伴い音速 が速くなっているが、これは曲げ荷重がかかることにより試 験片の圧縮側のき裂が閉口し、見かけの積層板剛性が上がっ たためと思われる。また、この図より明らかなヒステリシス が確認された。これは負荷時と除荷時でき裂開口状態が異な るためと思われる。

図6は曲げ変位による音速の変化を積層構成の異なる試験 片で比較した図である。[(0/90 $\left.{ }_{2 \mathrm{~S}}\right]$ よりむ $\left[(0 / 90)_{3 \mathrm{~S}}\right]$ の試験片 の方が音速の上昇が大きいことが確認できた。これは、積 層数が多い試験片の方が、曲げによるき裂閉口がより多く 生じたからだと思われる。

\section{4.おわりに}

超音波による FRP 積層板の非破壊損傷評価における曲げ 荷重の影響を評価するために、曲げ荷重を段階的に変化させ ながら損傷、非損賃の FRP 積層板の音速を測定した。その 結果、以下のことが分かった。

(1) 損傷後はき裂の閉口効果を反映し、負荷に伴い音速が速 くなることが確認できた。

(2) 試験片に曲げ荷重を段階的に負荷した場合と段階的に 除荷した場合で音速変化にヒステリシスが確認された。

(3) 穦層数が多いほど音速の上昇傾向が大きいことが確認 できた。

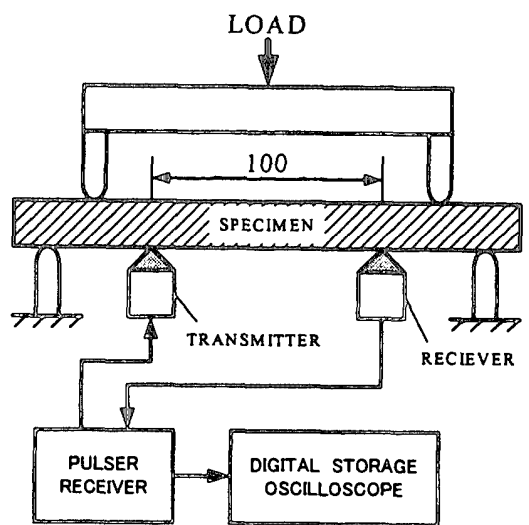

Fig.3 Experimental-setup for ultrasonic testing.

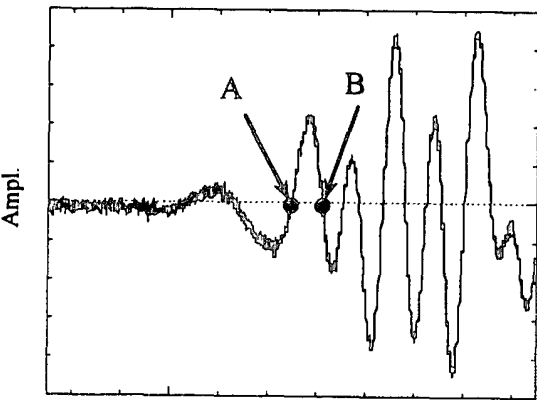

Time $[\mu \mathrm{s}]$

Fig.4 A detected waveform.

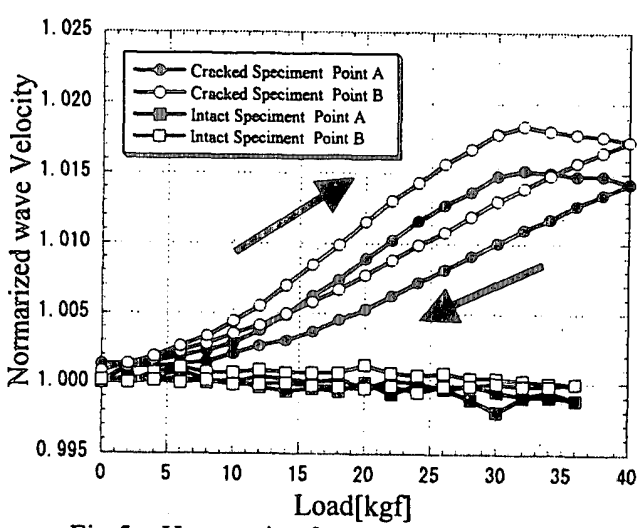

Fig.5 Hysteresis of wave velocity $\left[(0 / 90)_{3 s}\right]$.

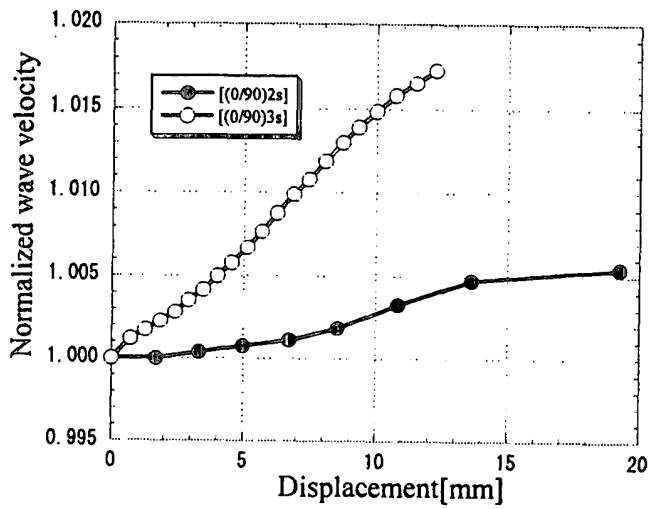

Fig.6 Comparison of wave velocity between different laminate configulations. 